our attention to the sampling method of the cecal contents, the results obtained by us (Tables III-2 and IV) did not support their result, showing an approximately uniform distribution of radioactivity regardless of sampling methods. These results show a very effective mixing and and movement of the entire cecal contents.
Acknowledgements The authors wish to express their hearty thanks to Ass. Prof. M. Ikeda and Mr. T. Hayama, Univ. of Tokyo, for their kind operation of sewing the abdominal window in Rabbit I and to Mr. K. Miyano, Univ. of Niigata, for his kind guidance in the surgical operation of sewing the abdominal window.

[Bull. Agr. Chem. Soc. Japan, Vol. 24, No. 6, p. 547 554, 1960]

\title{
Determination of Nucleic Acids in Yeast from the Viewpoint of Elution Behavior of Acid-Soluble Compounds*
}

\author{
By Yoshiro Kurorwa and Naoki Hashimoto \\ Amagasaki Laboratory, the Research Laboratories of Kirin Brewery Co. Ltd., Amagasaki, Hyogo Prefecture \\ Received January 19, 1960
}

It was reported ${ }^{1)}$ previously that Ogur and Rosen's method for the determination of nucleic acids should be applied to fresh or durable yeast, after a freezing pretreatment with dry ice and ether. The fractionation of nucleic acids from the frozen yeast should precede with a complete elimination of alcohol-ether-soluble and acid-soluble compounds. It has been found that in Ogur and Rosen's method, the elimination of the former compounds is complete, but the removal of acid-soluble compounds is unsatisfactory in the case of yeast.

In order to improve this defect, the best conditions for the elution of acid-soluble compounds have been investigated in detail, and it has been found that water is the most suitable solvent.

Many difficulties have been encountered in applying the method for the determination of nucleic acids in animal tissues to fresh microorganisms. One of the authors applied Ogur and Rosen's method ${ }^{23}$ to fresh or durable yeast and found that this method was unsatisfactory, because RNA could not be extracted completely

\footnotetext{
The following abbreviations are used: $\mathrm{P}_{o_{2}}$ orthophosphoric acid phosphorus; $\mathrm{Pp}$, polyphosphoric acid phosphorus; $\mathrm{Pt}$, toral phos phorus; RNA, ribonucleic acid; RNAP, ribonucleic acid phosphorus; DNA, disoxyribonucleic acids; DNAP, disoxyribonucleic acid phosphorus; PCA, perchloric acid; TCA, trichloroacetic acid.

* The content of this report was previously announced in the annual meeting of the Agr. Chem. Soc. Japan held on April 3rd, 1958.

1) Y. Kuroiwa and Y. Horie, This Bulletin, 19,35 (1955).

2) M. Ogur and G. Rosen, Arch. Biocbem. Biopbys., 25, 262 (1950).
}

by their procedure. Therefore, this method was modified by introducing the freezing pretreatment with dry ice and ethyl ether, as reported in the previous paper ${ }^{12}$.

Among the procedures involved in their method, the removal of alcohol-ether-soluble and acid-soluble compounds is very important, which precedes the fractionation of nucleic acids, because alcohol-ether-soluble and acidsoluble compounds absorb ultraviolet light at almost the same wave-lengths as RNA does.

The conditions for the complete removal of such compounds have been investigated, and it has been found that the use of water, in 
place of $0.2 \mathrm{~N}$ perchloric acid, is most suitable for the elution of acid-soluble compounds. By the use of both the freezing pretreatment and the extraction with water, a modified method for the determination of nucleic acids in fresh or durable yeast is presented in this papar.

\section{Method for the Determination of Nucleic Acids in Fresh or Durable Yeast.}

Two grams of pressed yeast, equivalent to about $500 \mathrm{mg}$ of dry matter, is weighed in a centrifugal tube, the water content adjusted to $80 \%$ and $2 \mathrm{~g}$ of dry ice and $2 \mathrm{ml}$ of ethyl ether are added, and the whole is frozen at $-70^{\circ} \mathrm{C}$ overnight in a Dewer vessel filled with dry ice ${ }^{1}$.

After the frozen yeast is melted in $20 \mathrm{ml}$ of ice-cold ethanol, the extraction of alcohol-soluble compounds as well as the dehydration of the yeast is repeated three times with $20 \mathrm{ml}$ portions of ice-cold ethanol as rapidly as possible, while the enzyme action is suppressed. Then, the residual yeast is extracted three times with $20 \mathrm{ml}$ portions of ethanol-ether mixture $(3: 1 \mathrm{v} / \mathrm{v})$ at $90^{\circ} \mathrm{C}$ for three minutes to remove alcohol-ethersoluble compounds and to destroy the enzymes involved in the yeast and dried in a centrifugal tube in a desiccater.

This dried sample is extracted for ten minutes with $5 \mathrm{ml}$ of ice-cold water and centrifuged for ten minutes. This process is repeated ten times in order to eliminate acidsoluble compounds completely.

In order to extract RNA, the residue is suspended in $5 \mathrm{ml}$ of $\mathrm{I} \mathrm{N} \mathrm{PCA} \mathrm{and} \mathrm{stored} \mathrm{at}$ about $0^{\circ} \mathrm{C}$ overnight and centrifuged. Further the extraction with $5 \mathrm{ml}$ of $1 \mathrm{~N}$ PCA for thirty minutes and the centrifugation for ten minutes are repeated fourteen times. The centrifugates are combined and filled up to $100 \mathrm{ml}$.

In order to extract DNA, the final residue is suspended in $5 \mathrm{ml}$ of $0.5 \mathrm{~N} \mathrm{PCA}$ and extracted at $70^{\circ} \mathrm{C}$ for twenty minutes. This extraction at $70^{\circ} \mathrm{C}$ is repeated three times and all the centrifugates are combined and made up to $25 \mathrm{ml}$.

The optical density of RNA is measured spectrophotometrically at $260 \mathrm{~m} \mu$ with $10 \mathrm{~mm}$ absorption cells, after $1 \mathrm{ml}$ of the extract is diluted to $25 \mathrm{ml}$.

DNA is determined colorimetrically by the use of the reaction with diphenylamine ${ }^{3)}$ as follows; one volume of the extract is mixed with two volumes of diphenylamine reagent and the mixture is boiled for five minutes and rapidly cooled. The intensity of color is measured spectrophotometrically at $600 \mathrm{~m} \mu$ after the mixture is allowed to stand for twenty minutes.

When the optical densities for RNA and DNA are expressed as $x$ and $y$ respectively, RNAP and DNAP in $1 \mathrm{~g}$ of solid yeast are calculated by the following formulae;

$$
\begin{aligned}
& \mathrm{RNAP}=2500 \times x \times 1 / 0.343 \times w \mu \mathrm{g} . \\
& \mathrm{DNAP}=75 \times y \times 1 / 0.047 \times w \mu \mathrm{g} .
\end{aligned}
$$

where, $w$ indicates the weight of the sample on dry basis in grams, and 0.343 or 0.047 indicates the optical density for $1 \mu \mathrm{g}$ RNAP or $1 \mu \mathrm{g}$ DNAP per $\mathrm{ml}$.

\section{EXPERIMENTAL}

All assay data were expressed per $2 \mathrm{~g}$ of pressed yeast throughout this paper. Yeast samples used in these experiments were prepared as follows; $2 \mathrm{~g}$ of pressed yeast, well washed with cold water, was weighed and frozen as described in the previous paper ${ }^{1)}$.

RNA was estimated spectrophotometrically by measureing the optical density at $260 \mathrm{~m} \mu$ and the colorimetric method by orcinol reaction ${ }^{4}$ was also used in some cases. DNA was estimated by the colorimetric method with diphenylamine and by the spectrophotometric method at $268 \mathrm{~m} \mu$. Phosphorus was estimated by Allen's method's?

$\mathrm{D}_{\text {ien }}$ indicates the optical density measured spectrophotometrically at $260 \mathrm{m \mu}$ using $10 \mathrm{~mm}$ absorption cells, when all the extracts are combined and made up to a definite volume.

1) Extraction of Alcohol-Ether-Soluble Compounds.

In order to remove alcohol-ether-soluble compounds, which interfere with the determination of nucleic acids, Ogur and Rosen's method prescribes that the lomo-

3) 2. Dische, Microchemie, 2, 26 (1930).

4) W. Mejbaum, Z. Pbysiol. Chem., 258, 117 (1930).

5) R.J.L. Allen, Biocbem. J., 34, 858 (1940). 
Determination of Nucleic Acids in Yeast from the Viewpoint of Elution Behavior of Acid-Soluble Compound.

genized sample should be extracted twice with ethanol at $4^{\circ} \mathrm{C}$, followed by repeated extraction with ethanolether mixture $(3: 1 \mathrm{v} / \mathrm{v})$ for three minutes in a boiling water bath.

However, it does not prescribe any relationship between the amount of the sample and the volume of the solvents. For the purpose of working out at the best condition to elute alcohol-ether-soluble compounds, the frozen yeast was extracted under the conditions described in Fig. 1.

It is recognized that alcohol- and alcohol-ether-soluble

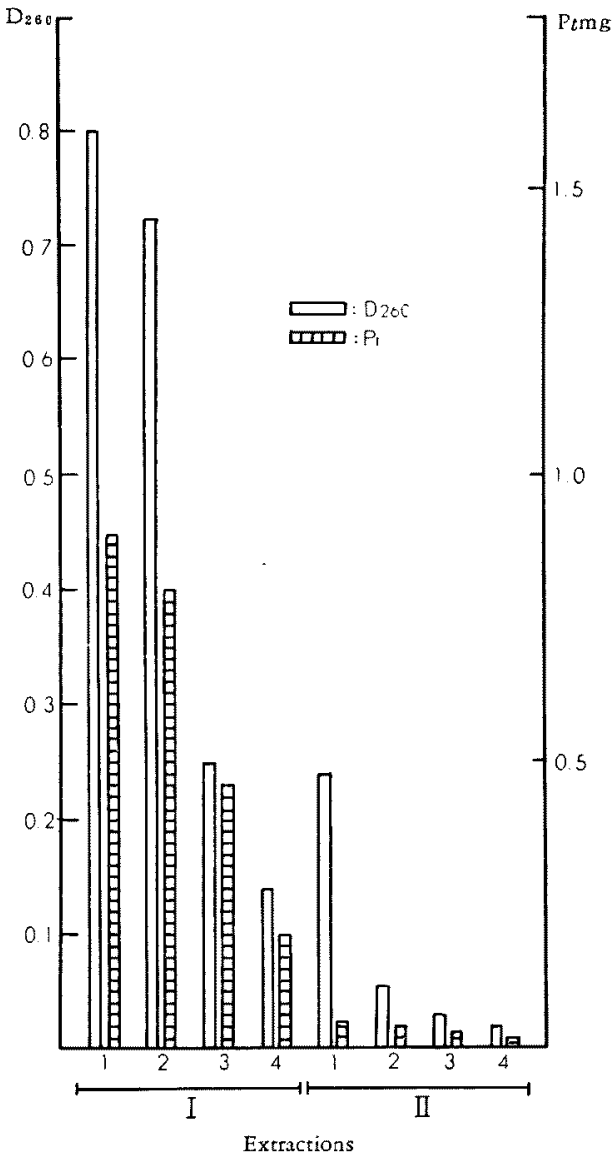

FIG. 1. Aspect of Extraction of AlcoholEther-Soluble Compounds.

The frozen yeast was extracted with four $20 \mathrm{ml}$ portions of ethanol at $0^{\circ} \mathrm{C}$ for $10 \mathrm{~min}$. (I) and the residual yeast was extracted four times each with $20 \mathrm{ml}$ of ethanol-ether mixture $\left(3: 1 \mathrm{v} / \mathrm{v}\right.$ ) at $90^{\circ} \mathrm{C}$ for $3 \mathrm{~min}$. (II). The centrifugate of each run was made up to $100 \mathrm{ml}$ and the optical density and $P t$ were derermined. compounds can be eluted almost completely when extracted each four times.

Next, the frozen yeast was divided into two parts. One part was extracted three times each with ethanol and with ethanol-ether mixture, and the other part, four times each. After these repeated procedures for the removal of alcohol-ether-soluble compounds, RNAP and $\mathrm{P}_{t}$ in the RNA fraction were estimated. A good agreement between the both values was seen for the two runs.

Hence, the removal of alcohol-ether-soluble compounds is complete, when $2 \mathrm{~g}$ of pressed yeast kept frozen overnight is extracted three times with $20 \mathrm{ml}$ portions of ethanol at $0^{\circ} \mathrm{C}$ for ten minutes and then extracted three times with $20 \mathrm{ml}$ portions of ethanol-ether mixture (3:1 $\mathrm{v} / \mathrm{v}$ ) at $90^{\circ} \mathrm{C}$ for three minutes.

2) Extraction of Acid-Soluble Compounds.

The complete extraction of acid-soluble compounds is an essential procedure in the determination of nucleic acids, since acid-soluble compounds have the ultraviolet light absorption at almost the same wavelengths as RNA does and easily contaminate the RNA fraction. Nevertheless only insufficient information is available concerning the removal of acid-soluble compounds. The procedures ever proposed are various ${ }^{\mathrm{f} \sim 83}$; for example, Ogur and Rosen proposed twice extraction with $0.2 \mathrm{~N}$

Table I. Extraction of ACid-Soluble Compounds WITH PCA, TCA AND WATER.

The yeast sample from which alcohol-ether-soluble compounds were previously removed, was extracted ten times with $5 \mathrm{ml}$ of $0.2 \mathrm{~N} \mathrm{PCA}, 10 \%$ TCA or water, at $0^{\circ} \mathrm{C}$ or $10^{\circ} \mathrm{C}$. All the centrifugates of each run were uniced and the values of $D_{260}, P_{t}$ and $P_{p}$ estimated. RNA and DNA were fractionated from the residues of each run obtained above and the quancities estimated.

Extraction of acid-soluble compounds

$\begin{array}{lccccccr}\text { with } & \text { at } & \mathrm{D}_{260}{ }^{*} & \mathrm{P}_{t} & \mathrm{P}_{p} & \overbrace{\mathrm{P}_{t}} & \mathrm{RNAP} \\ & & & \mathrm{Rg} & \mathrm{mg} & \mathrm{mg} & \mathrm{mg} & \mathrm{mg} \\ \text { Water } & 0^{\circ} \mathrm{C} & 0.073(0.22)^{* *} & 3.82 & 2.02 & 3.03 & 3.03 \\ 0.2 \mathrm{~N} \mathrm{PCA} & 0^{\circ} \mathrm{C} & 0.088(0.25) & 1.79 & 0.71 & 5.04 & 3.00 \\ 10 \% \text { TCA } & 0^{\circ} \mathrm{C} & 0.091(0.26) & 3.50 & 2.04 & 3.32 & 2.99 \\ \text { Water } & 10^{\circ} \mathrm{C} & 0.075(0.22) & 3.84 & 2.10 & 3.03 & 3.03 \\ 0.2 \mathrm{~N} \mathrm{PCA} & 10^{\circ} \mathrm{C} & 0.126(0.36) & 1.98 & - & 4.93 & 2.89\end{array}$

* when made up to $1 \mathrm{I}$.

** each optical density of acid-soluble fraction is calculated tem. porarily as RNAP.

6) W.C. Schneider, J. Biol. Chem., 161, 293 (1945).

7) L.H. Schmidr and S.J. Thanhauser, J. Biol. Chem., 161, 83 (1945).

8) F.J. DiCarlo and A.S. Schultz, Arch. Biochem. Biopbys, 17, 293 (1948). 


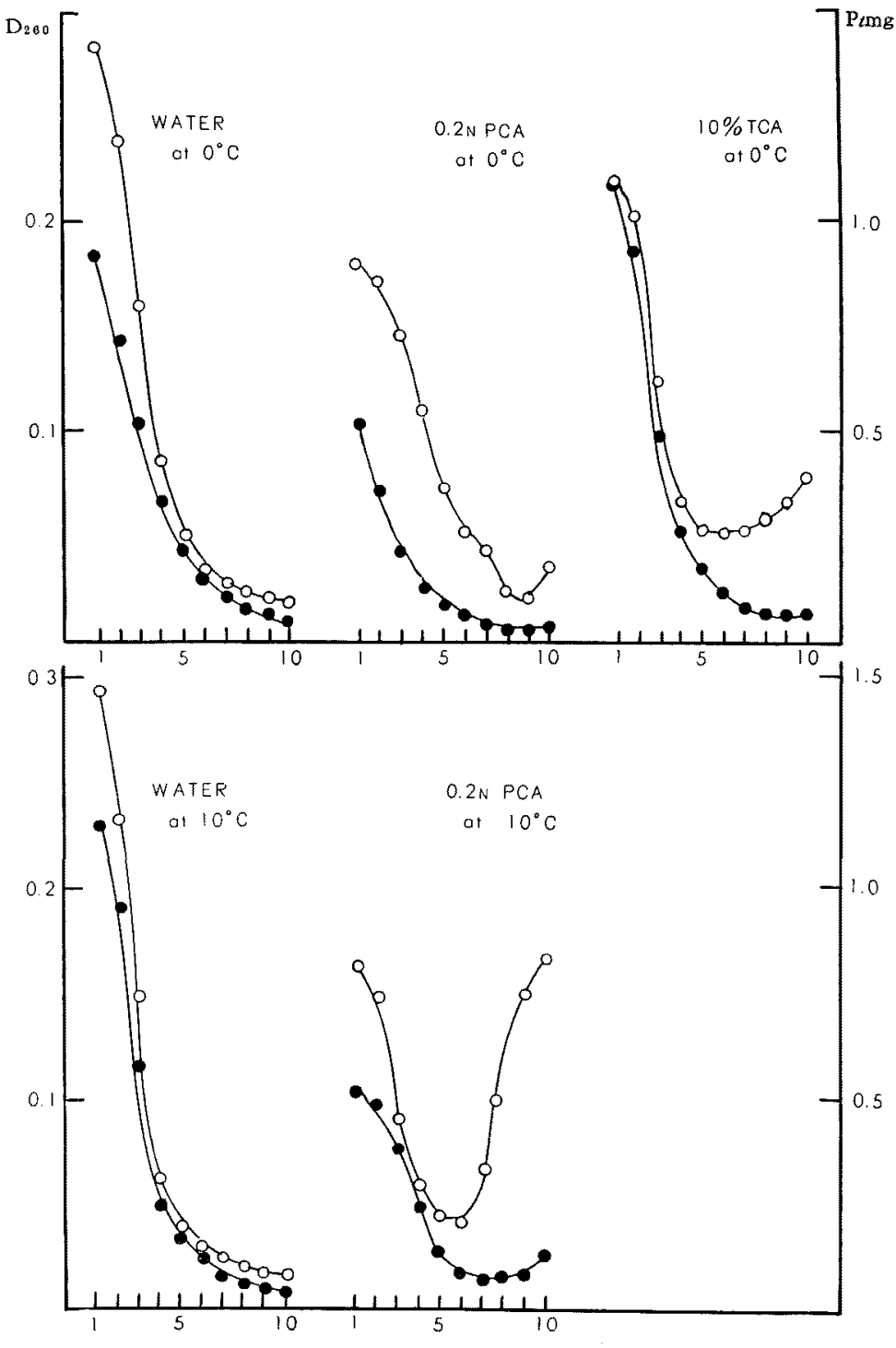

Extractions

FIG. 2. Further Examination of the Extraction of Acid-Soluble Compounds with TCA, PCA and Water.

Every centrifugate of each run described in Table I was made up to 100 $\mathrm{ml}$ and $\mathrm{D}_{200}$ and $\mathrm{P}_{t}$ were estimated.

$$
-\mathrm{O}-\mathrm{D}_{260}
$$$$
-P_{t}
$$ 


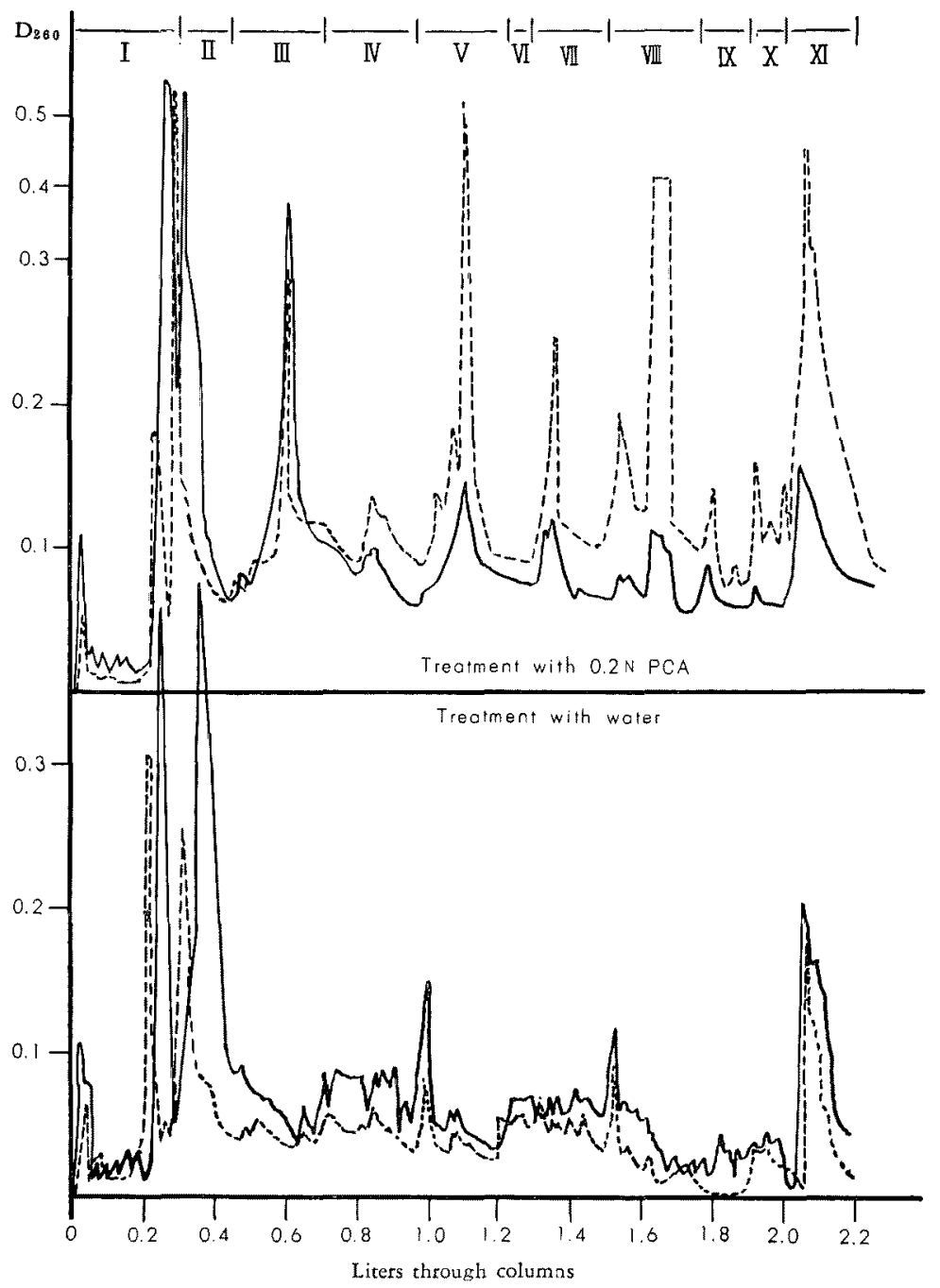

FIG. 3. Degradation of RNA and its Dissolution in the Acid-Soluble Fraction when Acid-Soluble Compounds were extracted repeatedly with PCA.

Acid-soluble compounds were extracted fifreen times with $0.2 \mathrm{~N}$ PCA or water. The centrifugates ranging from the first to seventh extraction (full line) and the eightb to fifteenth extraction (dotred line) were separately united and each mixture was analysed by ion exchange chromatography.

Ion exchanger: Dowex-1-chloride, $200 \sim 400 \mathrm{mesh}, 27 \mathrm{~cm} \times 2.3 \mathrm{~cm}^{2}$

Eluting solution: I; $0.005 \mathrm{~N} \mathrm{HCl}$, II ; $0.01 \mathrm{~N} \mathrm{HCl}$, III IX; $0.01 \mathrm{~N} \mathrm{HCl}+0.0125 \mathrm{~N}, 0.025 \mathrm{~N}, 0.05 \mathrm{~N}, 0.1 \mathrm{~N}, 0.2 \mathrm{~N}$, $0.4 \mathrm{~N}$ and $1 \mathrm{~N} \mathrm{NaCl}, \mathrm{X} ; 0.1 \mathrm{~N} \mathrm{HCl}, \mathrm{XI} ; 2 \mathrm{~N} \mathrm{HCl}$. 


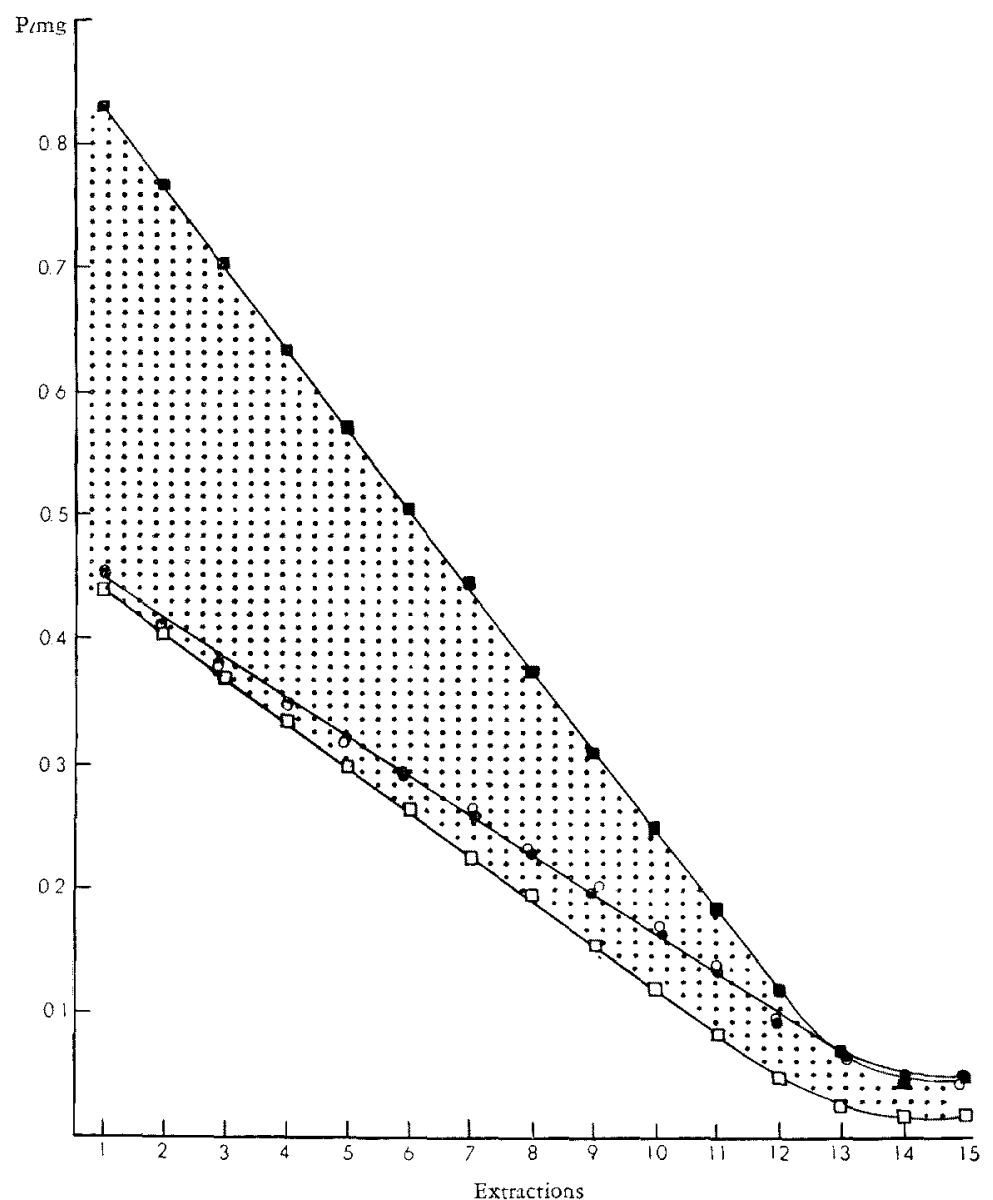

FIG. 4. Dissolution of Acid-Soluble Compounds into the RNA Fraction, on the Removal of Acid-Soluble Compounds with PCA at $0^{\circ} \mathrm{C}$.

Residual yeast used for the extraction of RNA was ptetreated with $0.2 \mathrm{~N} \mathrm{PCA}$ or water for remoyal of acid-soluble compounds. They were allowed to stand overnight in $5 \mathrm{ml}$ of $1 \mathrm{~N} \mathrm{PCA}$ at $0^{\circ} \mathrm{C}$, and then extracted fourteen times with $5 \mathrm{ml}$ of $1 \mathrm{~N}$ PCA for $30 \mathrm{~min}$. each time in the cold. The extraction of RNA was investigated by the estimation of $\mathrm{D}_{280}$ and $\mathrm{P}_{t}$.

$-O-$ RNAP, when extracted with water.
$-\square-$ RNAP, when extracted with PCA.

- $\mathrm{P}_{i}$, whein extracted with water.

PCA.

If acid-soluble compounds could be extracted completely, $P_{\imath}$ would be equal to RNAP in the RNA fraction. It has been apparently recognized as seen in Table I that acid-soluble compounds are incompletely extracted with TCA or PCA under the conditions described in Table $I$, because $P_{t}$ was always larger than RNAP in the RNA fraction. Only when the frozen yeast was extracted with water in place of with PCA or TCA, $P_{t}$ and RNAP agreed well with each other. This is a very important and interesting fact.

If RNAP in the RNA fraction is measured spectrophotometrically, the effect of the pretreatment at $0^{\circ} \mathrm{C}$ with either water, TCA or PCA on RNAP ssems to be within experimental error, because the amount of acid-soluble fraction estimated spectrophotometrically is much smaller than that of RNA. However, when one attempts to calculate RNAP from phosphorus content, 
the result becomes serious, because Ogur and Rosen's method consists of the fact that RNAP value measured spectrophotometrically coincides with that calculated from phosphorus.

In order to check the extraction of acid-soluble compounds in detail, $D_{a_{60}}$ and $P_{t}$ were chased in every centrifugate of each run described in Table $I$ and the results summarized in Fig. 2. A few times' repetition of the extraction, prescribed by Ogur and Rosen's method, of acid-soluble compounds with $0.2 \mathrm{~N}$ PCA was so insufficient that this may lead to erroneous estimation of RNA. However, even when the extraction is repeated further with the above-mentioned solvents, acid-soluble compounds could not be extracted completely; on the contrary, dissolution of RNA into the acid-soluble fraction was observed as described below; the values of $\mathrm{D}_{260}$ decreased gradually and then began to increase after about the fifth extraction. This fact may be caused by the degradation of RNA.

When water, in place of PCA or TCA, was employed for the extraction, acid-soluble compounds could be removed completely without any loss of RNA even at $10^{\circ} \mathrm{C}$.

In order to demonstrate the degradation and the dissolution of RNA, acid-soluble compounds extracted with water and with PCA were compared by ionexchange chromatography. Attempts were not made to identify each peak of the elution diagram in Fig. 3, but nucleotides ouget to be eluted in part II to $\mathrm{XI}^{9}$. In the case of the extraction with PCA, the amount of nucleotides contained in the combined centrifugate of the eighth to fifteenth extraction was larger than that in the combined centrifugate of the first to seventh extraction. This peculiar phenomenon could not be recognized by the use of the extraction with water.

Therefore, it would be reasonably considered in Table I that the small decrease in amount of RNAP on the extraction with TCA or PCA, might be due to the degradation of RNA to produce acid-soluble phosphorus.

From these results, it is desirable that acid-soluble compounds should be extracted with water ten times at a temperature below $10^{\circ} \mathrm{C}$.

3) Extraction of RNA.

For the extraction of RNA from the sample free from alcohol-ether-soluble and acid-soluble compounds, Ogur and Rosen's method prescribes in the case of root tips or pollen cells that the sample should be stored in 1 $N$ PGA for eighteen hours in the cold and then extrac-

9) E. Volkia and W.E. Cohn, J. Biol. Chem., 205, 767 (1953). tion twice more.

Effect of the pretreatment for the removal of acidsoluble compounds on the extraction of RNA was studied. For this purpose, the residual yeast which was pretreated with water or $0.2 \mathrm{~N}$ PCA for the removal of acid-soluble compounds, was extracted as shown in Fig. 4. The extractability of RNA was chased by the estimation of $D_{260}$ and $P_{t}$ in each centrifugate. It was recognized, as shown in Fig. 4 that when RNA was extracted from the residue treated with $0.2 \mathrm{~N} \mathrm{PCA}$, some part of the acid-soluble compounds was found in the RNA fraction in consequence of the insufficient extraction with $0.2 \mathrm{~N}$ PCA. The amount of contaminating acid-soluble compounds is shown by the dotted area, but these compounds do not seem to have absorption near $260 \mathrm{~m} \mu$. On the other hand, only when the yeast was pretreated with water, RNA free from acid-soluble compounds was obtained. This can be seen from the fact that the RNA value estimated from the optical density at $260 \mathrm{~m} \mu$ agreed with that obtained from the estimation of $\mathbf{P}_{t}$ in this fraction.

Fig. 4 also shows that RNA was sufficiently extracted after fifteen extractions with $1 \mathrm{~N}$ PCA. RNA fraction thus obtained was considered to be free from DNA, because diphenylamine reaction was negative.

\section{4) Extraction of DNA.}

According to Ogur and Rosen's method, DNA was extracted three times with $5 \mathrm{ml}$ of $0.5 \mathrm{~N}$ PCA at $70^{\circ} \mathrm{C}$ for twenty minutes from the residual yeast after the extraction of RNA in experiment 3).

The centrifugates were combined and the value of DNA calculated from the determination of optical density at $268 \mathrm{~m} \mu$ and that obtained by the colorimetric determination with diphenylamine were compared. A good agreement was observed between them, even when different solvents were used for the extraction of

TABLE II. EFFECT OF DIFFERENT PRETREATMENTS FOR THE REMOVAL OF ACID-SOLUBLE COMPOUNDS ON DNA CONTENT.

The residual yeast remained afrer the extraction of RNA in experiment 3) was extracted at $70^{\circ} \mathrm{C}$ in $5 \mathrm{ml}$ of $0.5 \mathrm{~N}$ PCA, three times. Three extracts were united and DNAP and $\mathrm{P}_{t}$ estimated.

Yeast residue after extraction RNA in Fig. 4

\begin{tabular}{ccr}
\multicolumn{2}{c}{ DNAP } & $\mathrm{P}_{t}$ \\
${_{265}} }$ & diphenylamine & \\
$\mathrm{mg}$ & $\mathrm{mg}$ & $\mathrm{mg}$ \\
.10 & 0.11 & 0.24 \\
& & \\
.10 & 0.10 & 0.23
\end{tabular}


acid-soluble compounds, as shown in Table II.

However, $P_{t}$ was appreciably larger than DNAP. This phenomenon appears to be due to the contamination with phosphoprotein ; this fact is well demonstrated by the fact that the bigher the extracting temperature, the more phosphorus was extracted and the less the phosphoprotein remained. This will be further discussed in a following paper ${ }^{10}$ ). Hence, in the determination of DNA, diphenylamine reaction is preferred to spectrophotometric measurement.

\section{DISCUSSION}

All the experiments described above were studied on yeast. Acid-soluble compounds were extracted incompletely with PCA or TCA, both from fresh and frozen yeast.

However, it is worth-while to note that acidsoluble compounds could be extracted completely, only when the frozen yeast was extracted with water. Such a phenomenon was also experienced by the present authors in the case of the isolation of thiamine $\mathrm{e}^{11}$ or glutathione $\mathrm{e}^{12,13)}$ from yeast, though these substances are apparently soluble in acid. This is considered to be due to the permeability of yeast cell membrane.

From this point of view, the following two experiments were undertaken. One experiment was on the sample of which cell membrane was easily destroyed in a mortar, for example, rabbit liver. In this case, the acid-soluble compounds were easily extracted with TCA or PCA, their dissolution into the RNA fraction being not recognized. The other was on the effect of destruction of the yeast cell membrane with sonic vibration. Two grams of pressed yeast was sonated at $10 \mathrm{Kc}$. in $20 \mathrm{ml}$ of ethanol for one hour. Measurement of the acid-soluble compounds and RNA after this treatment resulted in agreement with the values obtained from the yeast pretreated of freezing, as shown in Table III.

Therefore, the peculiar extraction of acid-

10) Y. Kuroiwa and K. Nakagawa, in press.

11) Y. Kuroiwa, un published.

12) Y. Kuroiwa, U. Ito, H. Horiguchi and S. Shimamoto, $J$. Japan Soc. Food and Nutrition, 2, 119 (1949).

13) Y. Kuroiwa, J. Japan Soc. Food and Nutrition, 2, 143 (1949).
TABLE III. EXTRACTION OF ACID-SOLUBLE CoMPOUNDS AND RNA FROM THE YEAST AFTER FREEZING OR SONATION.

Two grams of pressed yeast was sonated at $10 \mathrm{Kc}$. in $20 \mathrm{mi}$ of ethanol for $1 \mathrm{hr}$. or frozen with dry ice and ether. Acid-soluble compounds and RNA were extracted by the proposed procedure respectively.

Pretreatment Acid-soluble fraction RNA fraction

Freezing with dry ice and ether $\mathrm{P}_{t} \mathrm{mg}$ PNAP mg

Sonation

8.04

8.04

soluble compounds from fresh, durable or frozen yeast with TCA or PCA, may be due to the permeability of yeast cell membrane which is not easily destroyed mechanically.

\section{SUMMARY}

1) In the case of yeast, it has been demonstrated that acid-soluble compounds are not sufficiently eliminated when extracted twice with $0.2 \mathrm{~N}$ PCA according to Ogur and Rosen's method.

2) Even if the extraction with $0.2 \mathrm{~N}$ PCA is repeated further, acid-soluble compounds are not extracted completely; on the contrary, RNA begins to dissolve into the acid-soluble fraction.

3) It has been shown that these defects can be eliminated only when acid-soluble compounds are extracted with water instead of with $0.2 \mathrm{~N}$ PCA.

4) Based on the facts described above, the previous report on the determination of nucleic acids in fresh or durable yeast has been further modified, from the viewpoint of elution behavior of acid-soluble compounds.

Acknowledgement The authors would like to thank Messrs. M. Tokikuni and T. Kumazawa, the managing directors of Kirin Brewery Co. Ltd., who gave us the opportunity to publish this papar. We are grateful for many suggestions and the continued interest of Dr. Y. Umeda, the president of the Research Laboratories of Kirin Brewery Co. Ltd., and Dr. Y. Okuda, a member of the Japan Academy and the former president of our Research Laboratories. 